\title{
Book Reviews - Livres nouveaux - Buchbespreehungen
}

Cortone, A Handbook of Therapy. Published by the Scientific Staff of Merck (North America) Inc. New York 1953. 129 pages, 30 coloured plates, numerous figures, tables and references. It is well-known that the first synthesis of Cortisone was achieved in the Merck Research Laboratories by Dr. L. H. Sarett in 1946. The Merck team, in close co-operation with Dr. Kendall and his co-workers at the Mayo Foundation, subsequently succeeded in synthesising this hormone on a large scale, and by 1948 produced amounts sufficient for clinical trial. The first therapeutic injection of Cortisone in a patient with rheumatoid arthritis was made by Dr. Hench on 21 st September, 1948, and the dramatic effect of this injection - the start of a new and hopeful era in medical science - is also well-known. Since then the field of usefulness of Cortisone has broadened tremendously, to include allergic as well as rheumatic conditions: status asthmaticus, skin and eye affections of allergic origin, and many other disorders.

The methods of producing Cortisone have improved considerably; and today, in spite of steadily increasing therapeutic use, we are assured of an adequate supply. Early in 1950, N. L. Wendler, R.P. Graber, R. E. Jones and M.Tishler, at the Merck Laboratories, succeeded in synthesising Hydrocortisone, which is probably the principal corticoid with anti-inflamatory activity at tissue level. In the present monograph, the scientific staff of Merck Inc. have summarised the data on the therapeutic use of Cortisone and Hydrocortisone. Part I is devoted to a general review of the diseases in which Cortisone is indicated and details the place of Cortisone in the pattern of treatment. Part II covers the various diseases in which Cortisone or Hydrocortisone are of known value. Representative case-histories, excellent photographs and informative tables show the profound clinical and metabolic effect of these hormonal agents in the range of conditions so far treated. Part III includes valuable chapters on tolerance and on the detection and prevention of side effects. The development of Cortisone research and production, and the physiological considerations which form the basis of Cortisone therapy, are also reviewed. The more important references are listed at the end of each chapter.

This monograph is an invaluable and practical aid, and gives all the infor mation in the use of Cortisone therapy at present available in a most instructive and convenient form. Paul Kallós, Helsingborg.

336 Book Reviews - Livres nouveaux - Buchbesprechungen

Hans Selye: The Story of the Adaptation Syndrome. Acta Inc., Montreal 1952. 225 pages, numerous figures and tables.

In this short, well-written book, Selye reviews the fascinating story of the Adaptation Syndrome in the form of seven "informal lectures". The text is easy to follow, and excellent illustrations help to clarify the complicated interaction between different organs which results in the adaptation syndrome and at times in the diseases of adaptation.

Those interested in these important problems will appreciate this excellent summary. Paul Kallós, Helsingborg. 
E. Noble Chamberlain: Symptoms and Signs in Clinical Medicine. An Introduction to Medical Diagnosis. Fifth Edition. John Wright \& Sons, Bristol 1952. 480 pages, 354 illustrations, 19 in colour.

Das wohlbekannte Buch liegt nun in 5. Auflage vor. Wie Dr. Chamberlain in seinem Vorwort hervorhebt, wurden die meisten Kapitel völlig neu bearbeitet, und man kann mit Genugtuung feststellen, daß diese Neubearbeitung ausgezeich-net gelungen ist. Das Buch enthält alles Wesentliche und ist «up to day», wobei es Dr. Chamberlain geglückt ist, den Umfang nicht zu erweitern. Dadurch ist die Handlichkeit und Übersichtlichkeit beibehalten worden. Das Buch ist als Lehrbuch gedacht, aber auch der Fortgeschrittene wird es mit viel Nutzen lesen. Neu ist ein Kapitel über die Anamnese, das mir besonders lesenswert erscheint. Das Buch ist eine systematische Anleitung zur exakten Untersuchung des Patienten und ist nach Organsystemen eingeteilt. Nach Besprechung der äußeren Krankheitszeichen wer-den somit die Symptome gründlich besprochen, welche bei Erkrankungen der Atmungs-, Zirkulations-, Urogenital- und Digestionsorgane zu beobachten sind. Dann folgt eine ausführliche Besprechung der Symptomatologie der Krankheiten des hämatopoetischen und des Nervensystems. Typische Röntgen- und Laborato-riumsbefunde sind ebenfalls eingehend und anschaulich besprochen. Aus didakti-schen Gründen ware vielleicht eine andere Einteilung des Stoffes, entsprechend dem Titel, nach Krankheitszeichen und Symptomen, besser gewesen. Das einzige Symptom, das selbständig besprochen wird, ist das Fieber.

Paul Kallós, Hälsingborg.

/.jF. A. McManus (Editor) : Progress in Fundamental Medicine. Lea \& Febiger, Philadelphia 1952. 316 pages, 74 ill., 2 color plates.

This is the first volume of a new and interesting series, which will publish "authoritative discussions of current pathologic and clinical importance". The present volume contains articles on such different topics as "Melanotic Tumors of the Skin" (by /. A. Cunningham), "Carcinoma Cervix Uteri”" (L. D. Stoddard, W. C. Knyler) and "Non-Silica Pneumoconioses" (]. P. Wyatt). The excellent contributions by P. R. Cannon on "Parenteral Nutrition with Protein Hydrolysates" and by P. Klemperer on the "Pathology of Systemic Lupus Erythematodes" are of special interest to allergists. G. K. Mallory and T. B. Mallory contribute a masterly article on "The Liver". The Editor, /. F. A. McManus, presents a survey of techniques for the histochemical approach to pathology. M. Klingman discusses the diagnosis of fungus infections. /. C. Paterson $1 / 8$ contribution on "Cor onary Artery Disease" is also' very interesting and well written. It is to be hoped that Dr. McManus will continue to edit such informative volumes. It is an excellent beginning and a great promise for the future. Print and illustrations are also excellent. Paul Kallós, Helsingborg. 